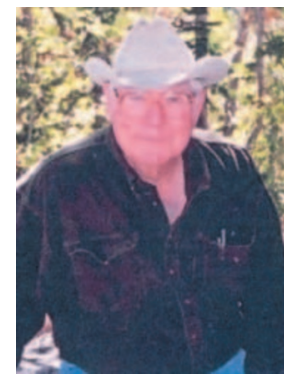

Thad Box

\title{
Poetry and the Land
}

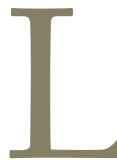

ast January I received a request from Karen Launchbaugh to write a verse to be used as an invocation at the banquet of the Society for Range Management. Poetry is a very special and powerful form of communication. Some people are inspired by it, others are put off by it, and some just plain don't get it. It comes in many styles. Because my poetry is different from some poetry written and enjoyed by many SRM members, I hesitated. My poems are mostly talking to myself. But I find it hard to reject a request from Karen. I decided, with some trepidation, to write something Octavio Paz might call "a ramble through the night."

\section{BREAKING BREAD ON THE PALOUSE AN INVOCATION}

Let us celebrate our oneness with the land we serve each bite of lamb ties us to mountain meadows and sagebrush hills

each potato brings raindrops falling from the skies soaking through soil

bubbling down streams

wetting prairies where pronghorn and buffalo roamed

The land was different when the first human arrived walked across the Palouse eating what he could find multiplying his kind,

changing the land with spears and sticks

killing mice and mammoths

digging tubers from the soil

diverting streams, re-engineering the land without a plan

Then ships of mighty nations reunited continents where all living things had evolved in isolation

new diseases, plants and animals

raced ahead of conquering armies

changed the land

formed new connections

Cayuse horses became royal symbols in the Northwest

More humans came, bringing guns and wagons

and plows and trains and computers and smartphones.

as we applied each new technology

we distanced ourselves

from oneness with the land

dominating but realizing

we are stewards of a scarred system that must sustain us 
Some of us are as crisp as fresh picked greens

some bleed like a rare sirloin on a charcoal grill

others are like lentils, supplying protein without blood

together we bring

sweetness of an apple cobbler

wisdom of an aged cheddar

boldness of a Columbia Valley cabernet sauvignon

But land does not belong to us, we are part of the land our role is like a brain, thinking, planning, controlling we are responsible for health and well being

of our system

but the brain is not property of the heart. and the heart is not owned by the toes.

let us celebrate the bounty of our earth, let us be one with the land

Octavio Paz (1914-1998) experimented with poetry, trying to get his readers to think-to write their own poem as they read his. Paz was a Mexican poet, writer, and diplomat, who received the Nobel Prize for Literature in 1990. $\mathrm{He}$ said he wrote "little phrases" to allow other people to make their own poems in their heads. Some of Paz's poems are developed with the discipline of regular meter and rhyme most people expect. But in some of his most acclaimed verse he used other forms, especially when his message was to teach, to change behavior.

Paz's death in April 1998 caused me to rethink my own writing. I had almost given up writing poems after participating in a poetry reading at a long-past SRM meeting. As each poem was read, I felt more and more out of place. I criticize not the other writers. Their poems were good. Those assembled were far better poets than I. Their words, rhyme, and meter brought laughter to the bar. Performance appeared as important as the content.

My problem was not with the other poets or their style of writing. It was with me. Most cowboy poems are aimed at a specific audience. Some are oral history of the people who tamed the west. They are designed to make people laugh and appreciate the cowboy culture. That is a good thing. But it is not my thing.

The poets I most admire write, in May Swenson's words, standing on the end of the diving board, alone, naked, not thinking of the "how" or "why" or the best technique, but just the sensation ... not caring whether anyone watches or not.

Paz's death reminded me I wrote not to entertain, but to record a feeling, an emotion. The poetry book that most influenced my life is Dag Hammarskjöld's Markings. He, Pablo Neruda, and Paz wrote to change things. Paz said writers of his century are oppressed to be concerned with politics in the same way intellectuals of another century were oppressed by the church. He claimed he was just a translator with his poems.

Poets I admire write from the gut as well as from the heart. Like Swenson, they are not afraid to stand naked and alone. Like Paz, they are oppressed by a cause. I favor poetry taken to the people-in hospitals and bars, tire stores and city hall, in churches and SRM meetings. Poets I admire publish pamphlets and hand them out on street corners.

We land care professionals are oppressed to speak for the land. Poems - all kinds of poems - should be read at SRM meetings. They should be published in our journals. Whether cowboy poems, or rap songs, or sonnets or another form, they should be written in each person's most effective form. We should encourage our colleagues to write about the land and its people. If prose comes easier, write it. We use our writing, regardless of style, to teach about land and people. Whatever we read or publish, it should make people think, write, and act to make the world better.

Paz breathes no more, but his poems are with us. Few can be a Paz. I do not claim to be a poet, or a good writer. But I would like for my actions and my thoughts, like Paz's, to challenge readers to write poems in their hearts and become oppressed against the indignities that afflict the land we serve. And I would be pleased if I move readers to write rebuttals or agreement.

Little phrases are powerful tools, whether in prose or poetry or carved in granite. Whatever words we chisel in stone, scribble in greeting cards, publish in pamphlets, read in bars, or write in peer-reviewed journals, should make readers think - and then act. We are the voice of the land.

ThadBox,thadbox@comcast.net. 